\title{
Horizontal Expressions of Vertical Desires: Horizontal Effect and the Scope of the EU Fundamental Freedoms
}

\author{
Pedro Caro de Sousa*
}

\begin{abstract}
Traditional approaches to the debate on the so-called 'horizontal' effect of the EU fundamental freedoms tend to focus on whether these freedoms apply directly to private relationships. The main argument of this article is that these approaches are misguided: EU fundamental freedoms inherently affect private relationships as a consequence of their direct effect, but this can occur through a number of different legal mechanisms. In any event, and as emerges clearly from comparative constitutional law, differences in the way through which the fundamental freedoms filtrate to private relationships do not alter the substantial outcome of decisions concerning, or the legal framework applying to, those relationships. Accordingly, it is submitted that the debate on horizontal effect should be reframed as a debate about the scope of the fundamental freedoms. In particular, questions about whether private behaviour is susceptible of infringing the fundamental freedoms only need to arise in the absence of state action - as in all other cases the situation can be assessed through a review of the state measure regulating such behaviour. In relation to situations where there is an absence of state regulation, it is argued that only those private actions which are able to restrict the fundamental freedoms in a manner akin to state action should fall within the scope of the freedoms-and that, in these cases, the infringement of the fundamental freedoms should be ascribed to failures by a state to prevent the restrictive private behaviour.
\end{abstract}

\section{Keywords}

EU, fundamental freedoms, direct effect, horizontal effect, constitutional rights

Barrister of England and Wales; DPhil Oxon. The traditional academic disclaimer applies.

Copyright (c) the Author(s).

This work is licensed under a Creative Commons Attribution-NonCommercial-NoDerivs 3.0 License. 


\section{Introduction}

The present article will focus on whether private parties are directly bound by the EU fundamental freedoms ${ }^{1}$ and thereby deals with the question of the latters' so-called 'horizontal effect'-whether they apply to private relationships, and if so, in what way. It will begin by describing the case law of the Court of Justice of the European Union ('CJEU' or the 'Court'), following which a review of the literature on the topic will be pursued. While in both the case law and the literature it is generally accepted that at least some freedoms can have horizontal direct effect, in the latter one can also find a debate concerning whether (some of) the fundamental freedoms should have horizontal direct effect or not. It will be argued that this debate and the term 'horizontal direct effect' tend to conflate two different questions-whether the fundamental freedoms apply to purely private relationships, and whether such application is direct or indirect.

The conflation of these two questions leads to confusion and overlooks the fact that the fundamental freedoms, like other constitutional rights, can regulate private relationships in a variety of ways. National measures applying to private relationships must be interpreted in accordance with the fundamental freedoms, or, if such interprétation conforme is not possible, those national measures must be disapplied. Member states can also be condemned for their failure to act in such a manner as to ensure the protection of rights arising from the fundamental freedoms. Lastly, the fundamental freedoms can be applied directly to private relationships. Even though all these modes of application reflect some form of horizontal effect, only the last one can properly be called 'horizontal direct effect'. The existence of this plurality of horizontal effect types will be exemplified by an examination of different constitutional settings; this comparative constitutional analysis will also demonstrate how the application of constitutional rights to private relationships leads to the same substantive outcome regardless of the type of horizontal effect adopted. From this perspective, the relevant question is not so much whether the fundamental freedoms can have horizontal effect but in what circumstances private actions will fall within the freedoms' scope. This issue will

\footnotetext{
These are the economic free movement provisions concerning the free movement of goods, services, establishment, capital, and workers within the EU. They can also be called market freedoms to distinguish them from European citizenship, which deals with non-economic free movement.
} 
be reviewed, and it will be submitted that the scope of the fundamental freedoms should be the same for both public and private entities.

A second question is whether substantive equivalence means that the distinction between different types of horizontal direct effect is irrelevant. It will be submitted that this is not so, as this distinction has two types of consequences. The first arises from the possibility of civil liability for infringements of the fundamental freedoms. It has as its consequence that, in the exceptional case when a private action restricting free movement is not regulated by national legislation, liability can either be assigned directly to the private parties infringing upon the fundamental freedom, or be imputed to states due to their failure to ensure the protection of those freedoms against acts of private parties. Secondly, different types of horizontal effect lead to different institutions-in particular, courts and legislatures-being primarily responsible for the balancing of fundamental freedoms with other legitimate interests, particularly those arising from individual autonomy. ${ }^{2}$ It seems preferable that horizontal effect should apply through the imposition of positive duties on states, thereby both granting primary competence to de-centralised national legislatures to pursue the relevant balancing exercises and making states liable for most, if not all, infringements of the market freedoms.

\section{Preliminaries}

A number of preliminary points are in order. First, the expression 'horizontal effect' does not exclusively refer to relationships between private parties, the same way that vertical effect does not relate exclusively to relationships between the Union and member states. The term 'horizontal effect' can also cover the effect of Union law between member states, while vertical effect also extends to the relationship between the Union and individuals. ${ }^{3}$ Regardless, the expression 'horizontal effect' is commonly, and imprecisely, used by the academic literature to refer to the effect of the fundamental freedoms in purely private relationships-a usage which will be adopted in this article-even if it has never been used by the Court itself. ${ }^{4}$

${ }^{2}$ Even if these balancing exercises are ultimately always subject to review by the CJEU.

3 J Baquero Cruz, Between Competition and Free Movement (2002) 108.

4 J Krzeminska-Vamkava, 'Horizontal Effect of Fundamental Rights and Freedoms-Much Ado About Nothing? German, Polish and EU Theories Compared after Viking Line' [2009] Jean Monnet Working Paper 11/09, 7. 
It should also be noted that the absence of horizontal direct effect does not mean that the fundamental freedoms cannot affect private relationships, as demonstrated by the fact that under the preliminary ruling mechanism purely private disputes are decided in accordance with EU law. In this sense, it is not doubted that Treaty provisions can have horizontal effect, with private parties being empowered to claim rights deriving from fundamental freedoms even in private litigation. The relevant question regarding 'horizontal direct effect' is not whether private relationships can be directly affected by the fundamental freedoms, but whether individual conduct may itself infringe the rules on free movement; in other words, whether, in addition to a member state's activities, actions by a private party are susceptible of falling within the scope of the market freedoms. ${ }^{5}$ Inasmuch as the overwhelming majority of private actions will be regulated by some kind of state measure, it is only in the exceptional cases where this does not occur that the question of horizontal direct effect comes up-which is reflected in the limited number of cases on this topic when compared to the full body of free movement case law.

\section{Taking the case law at face value}

It is common, when analysing the CJEU's case law on the horizontal effect of the fundamental freedoms, to distinguish between the free movement of persons and the free movement of goods, a distinction which will be followed here for clarity of exposition. ${ }^{6}$

\subsection{Free movement of persons}

The question of whether private persons were bound by the free movement provisions was first addressed in Walrave, where it was held that the rules of an international sporting federation fell within the scope of the Treaty because the non-discrimination imperative did not apply solely to the action of public authorities, but also to rules of any other nature aimed at regulating, in a collective manner, gainful employment and the provision of services. ${ }^{7}$ This formulation was reiterated in subsequent cases that elaborated the justifications for why actions by private persons were directly subject to the provisions on

\footnotetext{
5 J Baquero Cruz, 'Free Movement and Private Autonomy' (1999) 24 ELRev 603, 605; D Chalmers, G T Davies \& G Monti, European Union law (2010) 274.

${ }^{6}$ Capital is usually ignored in these discussions.

${ }^{7}$ Case 36/74 Walrave [1974] ECR 1405.
} 
free movement of persons. These justifications boiled down to three different propositions: the effet utile proposition; the uniform application proposition; and the general wording proposition. ${ }^{8}$ The effet utile proposition points out that the fundamental freedoms create rights which courts must protect, and that the removal of obstacles to the free movement of persons between member states would be compromised if the abolition of state barriers could be neutralised by other obstacles originating from associations or organisations not governed by public law. The uniform application proposition points out that since working conditions in different member states are sometimes governed by provisions laid down by law or regulation, and sometimes by agreements and other acts concluded or adopted by private persons, to limit the scope of the fundamental freedoms to public acts would prevent them from being uniformly applied throughout the EU. Lastly, the general wording proposition points to the fact that there is nothing in the relevant provisions restricting the direct effect of the free movement of persons to public action. ${ }^{9}$

These reasons for finding that private actions can fall within the scope of the fundamental freedoms leave some questions unanswered. The most obvious one is whether private persons found to have infringed the free movement rights of others would be able to have recourse to the exceptions provided for in the Treaty, particularly since such justifications do not appear to be suited to private entities. The Court eventually held that there is nothing to preclude individuals or other legal persons from relying on justifications on grounds of public policy, public security or public health, as neither the scope nor the content of those grounds of justification is in any way affected by the public or private nature of the rules in question. ${ }^{10}$ Other unaddressed issues are what exactly a measure 'aimed at regulating in a collective manner gainful employment and the provision of services' is, and whether private actions not falling under this aegis can also restrict the free movement of persons. The former question was never answered by the Court ${ }^{11}$ but the latter question was addressed in

8 D Schaefer, Die unmittelbare Wirkung des Verbot der nichttarifären Handelshemmnisse (Art. 30 EWGV) in den Rechtsbezienhungen zwischen Privaten (1987) 147-54; T Körber, 'Innerstaatliche Anwendung und Drittwirkung der Grundfreiheiten' (2000) 35 EuR 932, 941; S Bogaert, 'Horizontality: the Court Attacks?' in Catherine Barnard and Joanne Scott (eds), The Law of the Single European Market (2001) 125.

9 Case 13/76 Donà v Mantero [1976] ECR 1333, Case C-415/03 Bosman [1995] ECR I-4921, Joined Cases C-51/96 and C-191/97 Deliège [2000] ECR I-2549, Case C-309/99 Wouters [2002] ECR I-1577, Case C-438/05 Viking [2007] ECR I-10779, Case C-341/05 Laval [2007] ECR I-11767.

${ }^{10}$ Bosman, above $\mathrm{n} 9$, para 86.

${ }^{11}$ It has been argued that it corresponds to what is known as Rechtsetzung durch Private or private 
Angonese, a case concerning a competition for a post with a private banking undertaking in Bolzano that required, as one of the conditions for entry into that competition, the possession of a certain certificate of bilingualism (in Italian and German) which could only be obtained in that Italian province. ${ }^{12}$ The Court decided that this measure discriminated on grounds of nationality and that the prohibition of discrimination applied equally to agreements intended to regulate paid labour collectively and to contracts between individuals, thus seemingly extending the Treaty's prohibition of discrimination on grounds of nationality to private relationships, at least in what concerns the free movement of persons. ${ }^{13}$ In the light of this case law, it is almost unanimously recognised (and rarely criticised from a normative standpoint) that the free movement of persons has horizontal direct effect. ${ }^{14}$

\subsection{Free movement of goods}

The unanimous acceptance of horizontal direct effect for the free movement of persons was mirrored up until recently by a near unanimous rejection of such an effect for the free movement of goods. An apparent consensus that Article 34 TFEU applied only to public measures emerged following some cases concerning intellectual property rights in the 1970's. ${ }^{15}$ In these cases, the Court sought to identify the IP right's 'specific object': for example, for patents the 'specific object' would be the right for the holder to be the first to place a patented product in a given EU market and enjoy the economic benefits arising from it. The exercise of the right to this 'specific object' would 'exhaust' the IP right, with the result that whenever the exercise of a right by a private party exceeded the 'specific object'-for example, if the patentee tried to prevent importation of the product into his own member state when such product had already been lawfully marketed in another member state-such exercise would be considered

\footnotetext{
legislation in German doctrine. See Cruz, above n 5, 616-9.

${ }^{12}$ Case C-281/98 Angonese [2000] ECR I-4139.

${ }^{13}$ Ibid, para 34 . This leaves open the question of whether non-discriminatory private measures which do not regulate in a collective manner can also fall within the scope of the freedoms, a question still unaddressed by the Court.

${ }^{14}$ S Weatherill, 'Discrimination on Grounds of Nationality in Sport' (1989) 9 YEL 55, 90; J-C Séché, 'Quand les juges tirent au but: l'arrêt Bosman' [1996] CDE 355, 361. But critical analyses do exist: see Weatherill, 65-6; R Streinz, Europarecht (2001) 285.

${ }^{15}$ See, inter alia, Case 78/70 Deutsche Grammophon [1971] ECR 487, Case 15/74 Centrafarm v Sterling [1974] E.C.R. 1147, Case 16/74 Centrafarm v Winthrop [1974] ECR 1183, Case 3/78 Centrafarm v American Home Products [1978] ECR 1823, Joined Cases 55/80 and 57/80 Musik-Vertrieb [1981] ECR 147.
} 
to infringe upon Article 34 TFEU. ${ }^{16}$ This doctrine seemingly implied that it was the private party's action that restricted free movement, leading to a lively academic debate on whether this was, or should be, the case. ${ }^{17}$ This issue was apparently resolved when the Court held that what fell within the scope of Article 34 TFEU were only the laws which granted private parties IP rights. ${ }^{18}$

It thus became settled law that the actions of private persons did not per se restrict the free movement of goods. ${ }^{19}$ But in two landmark decisions concerning state omissions the Court seemed to embrace a new approach. The first one, Commission $v$ France, concerned a failure by France to prevent actions by private parties which obstructed the free movement of fruit and vegetables originating from other countries. ${ }^{20}$ The second one, Schmidberger, dealt with the absence of actions by Austria to prevent a demonstration that resulted in the complete closure of a major transit route between northern Europe and northern Italy. ${ }^{21}$ In both cases the Court was asked to consider whether omissions by a member state to suppress individuals' activities impeding cross border trade restricted the free movement of goods, and in both cases the Court considered that they did. ${ }^{22}$ This approach was new in that, even though in both cases an assessment of the

${ }^{16}$ Case 187/80 Merck v Stephar [1981] ECR 2063, para 9-10; and Joined Cases C-267/95 and C-268/95 Beecham Group v Europharm [1996] ECR I-6285, para 33.

${ }^{17}$ Arguing for the direct horizontal effect of the fundamental freedoms, W van Gerven, "The Recent Case Law of the Court of Justice Concerning Articles 30 and 36 of the EEC Treaty' (1977) 14 CML Rev 5; P Pescatore, 'Public and Private Aspects of European Community Competition Law' (1986-1987) 10 Fordham Int'l LJ 373; M Waelbroeck, 'Les rapports entre les règles sur la libre circulation des merchandises et les règles de concurrence applicables aux enterprises dans la CEE' in F Capotorti et al (eds), Liber Amicorum Pierre Pescatore (1987) 782-6. Arguing against, G Marenco, 'Competition between National Economies and Competition between Businesses - A Response to Judge Pescatore' (1986-1987) 10 Fordham Int'l LJ 420; N MacGowan and M Quinn, 'Could Article 30 impose obligations on individuals?' (1987) 12 ELRev 163; E White, 'In Search of the Limits to Article 30 of the EEC Treaty' (1989) 26 CML Rev 235; K Banks \& G Marenco, 'Intellectual Property and the Community Rules on Free Movement: Discrimination Unearthed' (1990) 15 ELRev 224; and P Oliver, Free Movement of Goods in the European Community (2003) 76.

${ }^{18}$ See Case 19/84 Pharmon v Hoechst [1985] ECR 2281, para 22; Case 434/85 Allen and Hanburys [1988] ECR 1245, para 8-10; and Case C-316/95 Generics [1997] ECR I-3929, para 17.

${ }^{19}$ Joined Cases 177 and 178/82 Van de Haar [1984] ECR 1797, Case 311/85 Vlaamse Reisbureaus [1987] ECR 3801, Case C-159/00 Sapod Audic [2002] ECR I-5031. For a possible exception to this, see Case 58/80 Dansk Supermarked [1981] ECR 181. For the controversy around it, see Cruz, above n $5,608-9$.

${ }^{20}$ Case C-265/95 Commission v France [1997] ECR I-6959, para 31.

${ }^{21}$ Case C-112/00 Schmidberger [2003] ECR I-5659, para 64.

${ }^{22}$ However, the abstention to act should be reviewed according to the marginal review technique: see Commission v France, above n 20, para 52; and Schmidberger, above n 21, para 74. 
lawfulness of collective actions undertaken by private individuals was implied, the decisions did not prohibit obstacles erected through the conduct of purely private persons per se but focused instead on the absence of state action preventing such conduct. $^{23}$

On this basis, one could arguably distinguish between direct horizontal effect for persons-i.e. that it was possible for private action to restrict those free movement rights - and indirect state liability for goods-i.e. that even though private action would not be able to restrict this free movement right per se, states could still be held liable for their failure to regulate such private activity. This distinction, however, was apparently not followed by the Court in a dictum in Viking, a case on the right of establishment, which read the cases on goods as making it 'apparent that restrictions [on the free movement of goods] may be the result of actions by individuals or groups of such individuals rather than caused by the State', thereby apparently extending horizontal direct effect to Article 34 TFEU. ${ }^{24}$

\section{The traditional debate on horizontal effect}

The traditional academic debate on the horizontal effect of the fundamental freedoms originated with the IP rights cases reviewed above. In particular, this debate tried to identify the relative roles of competition law and of the fundamental freedoms - the latter being mainly addressed to public entities, while the former regulates private conduct. A consequence of this, as we shall see, was a focus on horizontal direct effect to the detriment of other types of horizontal effect.

A first current of this literature argued that, while the fundamental freedoms cover state action, private action should be covered exclusively by the provisions on competition law of Articles 101 and 102 TFEU; furthermore, it argued that if some situations were not regulated by either competition law or the market freedoms, these were not gaps to be filled but situations which were explicitly excluded from the scope of the Treaty in order to protect a sphere of regulatory

\footnotetext{
${ }^{23}$ A Arnull, D Wyatt \& A Dashwood, European Union law (2006) 155; G Orlandini, 'Right to Strike, Transnational Collective Action and European Law: Time to Move On?' (2007) Jean Monnet Working Paper 08/07, 23.

${ }^{24}$ Viking, above n 9, paras 62-63. See also D Wyatt, 'Horizontal Effect of Fundamental Freedoms and the Right to Equality after Viking and Mangold, and the Implications for Community Competence' (4) (2008) CYELP 1, 8.
} 
autonomy for the member states. ${ }^{25}$ An opposite current disputed these assertions on both descriptive and normative grounds. Descriptively, it argued that the Court had applied competition law and fundamental freedoms to the same situations, reflecting the existence of situations with both public and private elements. ${ }^{26}$ It pointed out that while competition law only applied to undertakings, this concept encompasses any entity engaged in an economic activity regardless of its legal status. ${ }^{27}$ This meant that public bodies, such as public authorities, state-owned corporations, bodies entrusted by the state with particular tasks, and quasi-governmental bodies could all be deemed undertakings and subject to competition law whenever they pursued an economic activity, and could thus fall within the scope of both free movement provisions and competition rules. ${ }^{28} \mathrm{Si}$ multaneously, even though actions by private persons did not fall within the scope of competition law when those persons were not undertakings, they could still fall within the scope of the market freedoms. ${ }^{29}$ From a normative perspective, it was argued that since both sets of provisions had as their goal the creation of the common market, free movement and competition law were complementary-but this in no way entailed they were mutually exclusive, or that a distinction on the basis of the public or private nature of a specific organisation was suitable. ${ }^{30}$

With the developments in goods relating to the impact of state omissions

${ }^{25}$ See C D Ehlermann, 'The Contribution of EC Competition Policy to the Single Market' (1992) 29 CML Rev 257; J Drexl, 'Competition Law as Part of the European Constitutions' in A von Bogdandy \& J Bast (eds), Principles of European Constitutional Law (2006) 642; Orlandini, above n 23, 8; J Snell, 'Private Parties and the Free Movement of Goods and Services' in M Andenas \& W-H Roth (eds), Services and Free Movement in EU Law (2002) 211-2. This position was sometimes also adopted by case law: see Van de Haar, above n 19, paras 11-4; Case 65/86 Süllhöfer [1988] ECR 5249, paras 11-3; Sapod Audic, above n 19, para 74.

${ }^{26}$ Vlaamse Reisbureaus, above $\mathrm{n} 19$. See K Mortelmans, 'Towards Convergence in the Application of the Rules on Free Movement and on Competition?' (2001) 38 CML Rev 613, 625.

${ }^{27}$ Case C-41/90 Höfner and Elser [1991] ECR I-1979, paras 21-2 and 74-5 and cases mentioned therein. See, for a detailed discussions, O Odudu, The Boundaries of EC Competition Law (2006) 23-45.

${ }^{28}$ R Whish, Competition Law (2009) 85-6; Mortelmans, above n 26, 634-5.

${ }^{29}$ Examples of private parties not being deemed undertakings can be seen in Case C-96/94 Spedizioni Marittima del Golfo [1995] ECR I-2883, paras 23-5; Case C-35/96 Commission v Italy [1998] ECR I-3851, paras 41-4; Case C-364/92 Eurocontrol [1994] E.C.R. I-0043, para 30; Case C-343/95 Cali \& Figli [1997] E.C.R. I-1547, para 23; Wouters, above n 9, para 57; Case C-67/96 Albany [1999] E.C.R. I-5751, para 60; Joined Cases C-115/97 to C-117/97 Brentjens' [1999] E.C.R. I-6025, para 57.

${ }^{30}$ Waelbroeck, above n 17, 781, 793; Pescatore, above n 17, 383-6; Cruz, above n 3; C Krenn, 'A Missing Piece in the Horizontal Effect: Horizontal Direct Effect and the Free Movement of Goods' (2012) 49 CML Rev 177, 205-6. 
and concomitant attribution of different types of horizontal effect to different freedoms, the traditional debate became descriptively obsolete in its failure to engage with the possibility of types of horizontal effect other than horizontal direct effect. In the light of this, some arguments were developed focusing not so much on the logic of horizontal effect but rather on the special status of people under EU law. These arguments take two different forms: a first version holds that the free movement of workers, due to its specific social significance and the fact that it does not fall within the scope of competition rules, is subject to special treatment; the second approach takes horizontal direct effect outside the realm of market integration into a general prohibition of discrimination based on human rights $^{31}$ and/or European citizenship. ${ }^{32}$

It can be said that the special status of workers is reflected in the general prohibition of discrimination on grounds of nationality by private employers resulting from Angonese and in the secondary legislation that has extended the prohibition of discrimination on grounds of nationality to collective agreements and individual employment contracts alike. ${ }^{33}$ This argument seems to be consistent with the Court's uniform application proposition reviewed above, which focuses on the existence of different modes of regulating employment in different member states. But even if one accepts a special normative underpinning for the free movement of workers, this seems unable to explain the Court's zigzags concerning the types of obligations the free movement of goods imposes on private persons (or on states concerning the behaviour of their citizens); it also fails to explain why the Court has up until now only protected the free movement of goods through indirect state liability, while granting horizontal direct effect to all provisions on the free movement of persons regardless of whether they relate to workers or not.

Another way to look at the case law is to argue that the direct horizontal effect of the free movement of persons derives from a privileged status of persons within the EU legal system. One line of this argument relies on the creation of EU citizenship and its impact on the normative underpinnings of

\footnotetext{
${ }^{31}$ To avoid confusions, and since the EU freedoms are already referred to as fundamental freedoms, whenever I refer to other fundamental rights protected in national or international legal orders they will be called human rights. This does not reflect any position on their relative importance, but is done merely for clarity purposes.

${ }^{32}$ Cruz, above n 3, 92; Chalmers et al, above n 5, 802; H Schepel, 'Constitutionalising the Market, Marketising the Constitution, and to Tell the Difference: On the Horizontal Application of the Free Movement Provisions in EU Law' (2012) 18 ELJ 177, 180; Krenn, above n 30, 184-5.

${ }^{33}$ Cruz, above n 3, 235; Cruz, above n 5, 619; Schepel, above n 32, 180. See also Case C-94/07 Raccanelli [2008] ECR I-5939.
} 
the market freedoms. ${ }^{34}$ Against this, it can be argued that: (1) the attribution of horizontal direct effect to the free movement of persons occurred in a period when the focus of the Court was on developing the free movement of goods and the case law seemed to attribute a secondary status to the other freedoms, so that it is unlikely that these normative justifications were at play; (2) that the justifications presented by the Court for the introduction of horizontal direct effect for the free movement of persons in no way seemed to indicate that the normative underpinning for such an introduction was the privileged status of those freedoms; and (3) that the introduction and development of European citizenship took place at the same time as the extension of the horizontal scope of the free movement of goods towards indirect state liability and actually occurred after developments concerning the horizontal effect of the free movement of persons (with the exception of the extension of the prohibition of discrimination on grounds of nationality to private employers).

A second type of extra-economic arguments focuses on the privileged status of the free movement of persons as human rights. ${ }^{35}$ This argument is related to, but distinct from the argument concerning European citizenship in that it refers us to discussions concerning the status of all the fundamental freedoms as human rights. ${ }^{36}$ The issue with this approach is that, even admitting arguendo that it is easier to consider the free movement of persons a human right than the free movement of goods or the free movement of capital, these latter freedoms can also be seen as a reflection of the right to conduct a business and the right to property (as recognised in the case law and in Articles 16 and 17 of the Charter of Fundamental Rights). ${ }^{37}$ Furthermore, an equivalent axiological status of all

\footnotetext{
${ }^{34}$ Krenn, above n 30, 186-91.

${ }^{35}$ Arnull et al, above n 23, 705-7; J Snell, 'And Then There Were Two: Products and Citizens in Community Law' in T Tridimas \& P Nebbia (eds), European Law for the Twenty-First Century, vol II (2004) 69-70.

${ }^{36}$ This is not to say that the fundamental freedoms are also fundamental human rights. Even though some authors espouse this view-see A Bleckman, 'Die Freiheiten des Gemeinsamen als Grundrechte' in R Bieber \& D Nickel (eds), Das Europa der zweiten Generation-Gedächtnisshrift für Christoph Sasse, vol II (1981) - the prevailing view seems to be that they are distinct because, while the fundamental freedoms are instrumental to the realisation of a market without internal frontiers, the goal of human rights is to protect essential areas of freedom resulting intrinsically from human dignity. See W Frenz, 'Grundfreiheiten und Grundrechte' [2002] EuR 603; and T Kingreen, 'Fundamental Freedoms' in Von Bogdandy \& Bast, above n 25, 567-71.

${ }^{37}$ Case C-280/93 Germany v Council [1994] ECR I-4973, para 78; Case C-200/96 Metronome [1998] ECR I-01953, para 21; Case C-228/98 Dounias [2000] ECR I-00577, paras 64-5. On the free movement of goods as an element of the right to trade, see Case 240/83 ADBHU [1985] ECR 531, para 9. See also Frenz, above n 36, 606-7; P Oliver \& W-H Roth, "The Internal Market and
} 
the freedoms seems to be reflected in case law attributing fundamental status not only to the free movement of persons but also to the other freedoms. ${ }^{38}$ Even if this axiological equivalence is disputed, it must be remarked that, as with arguments focusing on European citizenship, the relevant developments in the case law occurred in a seemingly unrelated fashion to the appearance of normative arguments focusing on human rights. Accordingly, it is difficult to justify a differentiated treatment of the freedoms without relying on controversial a priori assumptions as to which rights are fundamental and which are not, particularly when such assumptions do not seem to be reflected in the existing body of law or in its development.

\section{An alternative approach}

\subsection{Fundamental freedoms and constitutional rights: a comparative constitutional exercise}

In searching for an alternative explanation for the phenomenon of horizontal effect of the fundamental freedoms, one can start from the following observation: even if it is disputed whether the fundamental freedoms are human rights or not, it seems to be consensual that both are types of judicially enforceable constitutional rights. Judicially enforceable human rights and fundamental freedoms grant rights to individuals against member states and the EU; both are applied by courts using the same analytical framework and proportionality test; and both are multi-level norms, regulating the interaction between member states and the EU by determining the vertical allocation of competences between them while simultaneously limiting the substantive scope of their powers. ${ }^{39}$ Adopting a constitutional rights perspective allows the problem of horizontal

the Four Freedoms' (2004) 41 CML Rev 407; P Oliver, 'Competition and Free Movement: Their Place in the Treaty' in Tridimas \& Nebbia, above n 35, 164.

${ }^{38}$ Oliver \& Roth, above n 37, 407. Situations where the Court referenced the fundamental nature of Treaty freedoms are various: see Case C-266/96 Corsica Ferries France [1998] ECR I-3949, para 8; Case C-34/98 Commission v France [2000] ECR I-995, para 49 (all four freedoms); Case C-19/92 Kraus [1993] ECR I-1663, para 28 (workers and establishment); Case C-385/99 Müller-Fauré [2003] ECR I-4509, para 72 (services); Schmidberger, above n 21, paras 50, 51 and 74 (goods); and Case C-483/99 Commission v France [2002] ECR I-4871, paras 45 and 48 (capital).

${ }^{39}$ Frenz, above n 36, 610-2; Kingreen, above n 36, 562-5; M Schillig, 'The Interpretation of European Private Law in the Light of Market Freedoms and EU Fundamental Rights' (2008) 15 MJ 285, 287. On the concept of human rights as rights with the particularity of setting limits to sovereignty, J Raz, Human Rights Without Foundations (2007) 14. 
effect of the fundamental freedoms to be compared with similar issues affecting constitutional rights throughout the world, since the problem of horizontal effect is not restricted to EU law; it is a pervasive question wherever judicially enforceable constitutional rights exist. ${ }^{40}$ As such, it is instructive to look at the state of the debate on the subject in the field of comparative constitutional law.

Different systems deal with the issue of horizontal effect of constitutional rights within a continuum that ranges from embracing direct effect to expressly refusing any kind of effect. While the former position was adopted in Ireland, the latter seems to find expression in the USA. An intermediate model postulates that constitutional rights influence but do not directly govern or control private law disputes between individuals: its main exponent is Germany. We shall now look at these models in turn.

The situation in Ireland implies the recognition of both direct and indirect horizontal effect. The more common effect seems to be the latter, which occurs whenever a fundamental constitutional right is deemed relevant to the proper interpretation of a right or obligation found in private law. Ireland also espouses a doctrine of positive state duties, which requires the state to protect, enforce or vindicate the constitutional rights of individuals. Lastly, Ireland also recognises direct horizontality and allows individuals to plead before the courts that their fundamental constitutional rights were infringed by a private party's action. Perhaps the most distinctive characteristic of the Irish system is the existence of a 'constitutional tort' permitting damages to be claimed in cases of both direct and indirect horizontal effect. ${ }^{41}$

In the US, the consensus is that the state action doctrine rejects all kinds of horizontal effect: apart from the Thirteenth Amendment, both the text of the Constitution and authoritative precedent make clear that the Constitution binds only governmental actors and not private individuals. What is more, courts are not under an obligation to interpret private law in accordance with the Constitution. ${ }^{42}$ However, this consensus has recently been challenged by the argument that even in the absence of any duty to interpret private law in accordance with the Constitution, the Supremacy Clause still renders all law fully, directly, and equally subject to the Constitution. This means that private law is subject to constitutional law, and since constitutional rights are

\footnotetext{
${ }^{40} \mathrm{M}$ Tushnet, 'The Issue of State Action/Horizontal Effect in Comparative Constitutional Law' (2003) 1 ICON 79.

${ }^{41}$ S Banda, 'Taking Indirect Horizontality Seriously in Ireland: A Time to Magnify the Nuance' (2009) 31 DULJ 263, 264-8.

${ }^{42}$ S Gardbaum, 'The Effect of Constitutional Rights' (2003) 102 Mich L Rev 387, 388.
} 
thus able to govern directly all private law, they also indirectly govern private relationships. Individual rights' provisions therefore have a significant impact on private persons by governing their legal relationships with each other-limiting what private actors can lawfully be empowered to do and which of their interests, preferences, and actions can be protected by law. The crux of the argument is that if private law becomes fully subject to constitutional rights scrutiny, the presence or absence of an interpretive duty has very little or no independent significance in determining whether there is horizontal effect or not. ${ }^{43}$ For example, in Shelley $v$ Kraemer, the Supreme Court held that an action by a court upholding a racially discriminatory contract between private persons constituted state action, which in turn meant that an injunction by a court upholding such a contract infringed the Constitution. ${ }^{44}$ In deeming the enforcement of a private contract by an individual court an instance of state action, the Supreme Court has, in an off-handed way, effectively imposed non-discrimination obligations on the lower court and directly affected an exclusively private law relationship. ${ }^{45}$ Hence, even though the state action doctrine forecloses the most direct way in which a constitution might regulate private actors-by imposing constitutional duties on them-it does not seem to rule out other, indirect ways of doing so. ${ }^{46}$

In Germany, our example of an 'intermediate model', three main theories can be said to exist regarding how constitutional rights should bind private parties. The 'unmittelbare, direkte Drittwirkung' approach sustains that constitutional rights should be directly effective in private relations, without any need for the intervention of public powers. The 'mittelbare, indirekte Drittwirkung' argues that constitutional rights are indirectly effective and therefore it is incumbent upon the legislator to regulate private relationships in such a way as to ensure respect for constitutional rights and upon the courts to interpret private law in accordance with them. ${ }^{47}$ A third theory, that of 'Schutzpflicht', sometimes seen as complementary to the other two, holds that constitutional rights impose

\footnotetext{
${ }^{43}$ S Gardbaum, 'The Myth and the Reality of American Constitutional Exceptionalism' [2008] Jean Monnet Working Paper 07/08, 50-61; Gardbaum, above n 42, 390-1.

${ }^{44}$ Shelley $v$ Kraemer, 334 US 1 (1948).

${ }^{45}$ Tushnet, above n 40, 81.

${ }^{46}$ Such as to develop expansive concepts of state: M Kumm \& V Comella, 'What Is So Special About Constitutional Rights in Private Litigation?' in A Sajó \& R Uitz (eds), The Constitution in Private Relationships (2005) 267-72.

${ }^{47}$ R Alexy, A Theory of Constitutional Rights (J Rivers tr, 2001) 355; C-W Cannaris, 'Drittwirkung der gemeinschaftsrechtlichen Grundfreiheiten' in H Bauer et al (eds), Umwelt, Wirtschaft und Recht (2002) 34; Krzeminska-Vamkava, above n 4, 11;JJ Gomes Canotilho, Direito Constitucional e Teoria da Constituição (1998) 422.
} 
protection duties on public powers, particularly the positive duty of the state to protect individuals from acts by third parties. Inasmuch as any such infraction can lawfully take place, the state is responsible for it. ${ }^{48}$

It is generally accepted that where the relevant provision expressly states that constitutional rights apply only against the state or also apply against private parties, the question is solved; the problem only exists in situations where no such specification exists. The prevailing practice, as seen in the case law of the German Federal Constitutional Court, is to adopt the mittelbare Drittwirkung theory, which broadly corresponds to indirect horizontal effect as described for Ireland. The origins of this can be traced back to the Lüth case, where it was stated that '[b]asic rights are primarily to protect the citizen against the state, but as enacted in the Constitution they also incorporate an objective scale of values which applies, as a matter of constitutional law, throughout the entire legal system. ${ }^{49}$ Constitutional rights are deemed to 'radiate' into all areas of the legal system, and must be taken into account when interpreting private law. Alongside this prevalence of indirect horizontal effect, practice seems also to have embraced a version of Schutzpflicht according to which courts have a duty, as state bodies, to hand down decisions that respect the constitutional rights of the parties by either interpreting private law in accordance with constitutional rights or, when such law is explicitly contrary to them, by considering it unlawful. ${ }^{50}$

Despite the existence of all these different approaches to regulating private conduct, it is generally accepted that no substantive difference arises from adopting horizontal direct or indirect effect, or even from adopting a doctrine requiring state action for the protection of constitutional rights: these approaches are outcome-neutral, even if their institutional mechanisms and supporting narratives vary from place to place. ${ }^{51}$ Practical differences concern the way

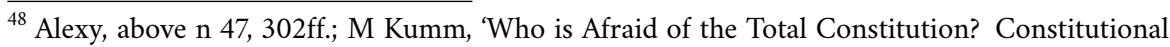
Rights as Principles and the Constitutionalization of Private Law' (2006) 7 GLJ 341, 350-1; Canotilho, above n 47,374, 384-5. This doctrine can also be found in the case law of the European Court of Human Rights since Belgian Linguistic case (No 2) [1968] 1 EHRR 252.

${ }^{49}$ Lüth BVerfGE 7198 , at 205.

${ }^{50}$ M Ruffert, Vorrang der Verfassug und Eigenständigkeit des Privatrechts (2001) 12-28, 144-52; Kumm, above n 48, 352. Similarly for Austria, see T Öhlinger, Verfassungsrecht (8 edn, 2009). On Schutzpflicht being incumbent on both courts and the legislature, see Hermes, 'Grundrechtsschutz durch Privatrecht auf neuer Grundlage?' [1990] NJW 1764, I Münch, J Ferrer i Riba and P Salvador Coderch, Zur Drittwirkund der Grundrechte (1998) 24-8.

${ }^{51}$ S Gardbaum, 'Where the (State) Action is' (2006) 4 ICON 760. On a plausible explanation of the historical-institutional background for the apparently restrictive 'state action' doctrine in the USA, see Kumm \& Comella, above n 46, 272-83.
} 
procedural questions are framed; under horizontal direct effect private parties would be the addressees of the decision instead of the public authority, and the actions of those parties would be reviewed instead of the relevant law or absence thereof. The substantive outcome, however, would be the same. Since courts are under an obligation to uphold constitutional law, the fact that parties may not invoke a direct constitutional infringement from the other party merely means that the question is replaced by the similar requirement that existing private law be interpreted in accordance with constitutional rights or be declared unconstitutional. The same balancing exercise is imposed on courts from a substantive perspective regardless of how the question is framed procedurally. ${ }^{52}$ Only exceptionally, in situations that are left untouched by the relatively thick regime of regulation nowadays applicable to private actors-in other words, when situations fall outside the control of the state's judicial apparatus (such as purely social arrangements)-will this not apply. In the absence of other procedural mechanisms allowing for judicial intervention, the only way for constitutional rights to apply in the private sphere is through the direct horizontal application of human rights extending the reach of judicial control. And even this can, in turn, be framed procedurally as a situation where a state omission occurred instead of a case of direct horizontal effect. ${ }^{53}$

In a sense, what this demonstrates is that the horizontal effect of constitutional rights is a typical doctrine of constitutional law, inherent to the creation of a system for their judicial adjudication. ${ }^{54}$ This might sound counter-intuitive, since it requires constitutional rights to be understood as imposing on governments a duty to create and protect areas of individual liberty against both public and private action, which is the opposite of the traditional view of constitutional rights and civil liberties as requiring the state not to act in order to create areas of individual liberty where public powers cannot interfere. As has been noted by Loughlin, this change in perspective is the result of:

[i]n modern constitutional settlements the basis of rights theories [having] dramatically shifted. Rights are no longer conceived as

\footnotetext{
52 Krzeminska-Vamkava, above n 4, 13-8; Kumm, above n 48, 352-9. This is only valid, however, assuming all law is subject to constitutionality review.

${ }^{53}$ M Tushnet, 'The Relationship between Judicial Review of Legislation and the Interpretation of Non-Constitutional Law, with Reference to Third Party Effect' in Sajó \& Uitz, above n 46, 170; Gardbaum, above n 51, 767. A good example of this seems to be Canada, where certain rules-such as common law-are largely exempt from judicial constitutional review. See C Saunders, 'Constitutional Rights and the Common Law' in Sajó \& Uitz, above n 46, 195-9.

${ }^{54}$ Tushnet, above n 53, 169.
} 
defining a zone of individual autonomy freed from governmental interest. Rights are now conceived to be part of the objective organizational principles of the constitutional order that has been instituted. Rather than being treated as pre-political rights that specify the limits of government, constitutional rights emerge from and obtain their realization only through the constitutional order that authorizes the office of government. [...] Whereas liberty previously was conceived as imposing limitations on law, liberty now becomes a state that is realized only through the operations of law. Instead of being treated as a natural condition-the product of pre-political social processes-liberty becomes a political condition that is itself institutionally shaped and normatively ordered. ${ }^{55}$

Under this framework, even negative constitutional rights-i.e. those rights that merely protect against the public abuse of power in order to create a zone of individual autonomy freed from governmental interference-are no longer understood to be satisfied by state abstention, requiring instead that such abstention be protected through a public apparatus that deters and punishes misconduct. The same can be said, a fortiori, of the infraction of constitutional rights by private parties: if private individuals infringing on rights are acting in accordance with laws creating and regulating private behaviour, this means that government action is present. Most of the so-called negative rights thus come to be understood as requiring governmental assistance, not governmental abstention; those rights cannot exist without public assistance to begin with, and no substantive difference arises from controlling private action directly or through the regulatory apparatus allowing for those actions. ${ }^{56}$

\subsection{On the 'horizontal effect' of EU fundamental freedoms}

The fundamental freedoms impose substantive constraints on the resolution of political questions by subjecting them to courts. They not only establish a comprehensive system of defences for individuals against potential excesses of member states, but also provide the basis for claiming that public authorities-be that the legislature, the executive or the judiciary-must intervene on behalf

\footnotetext{
${ }^{55}$ M Loughlin, Foundations of Public Law (2010) 369. Arguably, the best judicial expression of this can be found in the Lüth decision, above $\mathrm{n} 49$.

${ }^{56}$ Tushnet, above n 40 79; C Sunstein, 'State Action is Always Present' 3 Chi J Int'l L 465, 466-9.
} 
of rights-claimants in response to threats from third parties. ${ }^{57}$ Through the fundamental freedoms, individuals are granted rights which have to be protected by the state not only by ensuring that public authorities do not act in such a way as to infringe them, but also by effectively implementing the conditions whereby those rights can be enjoyed-if necessary, by protecting the right-holder against certain types of private action.

Like with other constitutional rights, choosing between different types of horizontal effect does not affect the substance of the fundamental freedoms, but merely what the legal actions to enforce them are. A good example of this is the IP rights saga described above. The controversy as to what infringed upon the free movement of goods-whether it was the exercise by the private party of its IP right or the fact that national law allowed for such a right in the first place-did not alter the substantive outcome: in the end, the situation was considered contrary to the free movement of goods regardless of the way in which it was framed. Hence, upholding the effect of fundamental freedoms in purely private relationships can be done by either granting them direct or indirect horizontal effect or by imposing on the state a duty to protect them, without any relevant substantive distinction arising from this. In the end, the outcome will be the same. $^{58}$

On the other hand, the application of constitutional rights to private law and to relationships between individuals does not prejudice any particular substantive outcome about where the relevant lines ought to be drawn; that will still depend on the substantive scope of rights and the delimitation of competing spheres of autonomy of the relevant right-holders, so that when applying constitutional rights in purely private contexts the autonomy interests of both parties need to be taken into account. ${ }^{59}$ What is relevant concerning the delimitation of competing areas of private autonomy is, first, what the scope of the relevant rights is-which effectively ensures a specific area of personal autonomy to begin with-and, second, what results from the balancing of these competing spheres of autonomy. ${ }^{60}$

What this means is that the choice between different types of horizontal effect does not lead to a specific substantive outcome being determined a priori, but merely to a change in the relevant institutional allocation of competences. The

\footnotetext{
${ }^{57}$ Kumm, above n 48, 343-4, relying on his concept of 'constitutional juristocracy' to describe such a system.

${ }^{58}$ Similarly, A-G Maduro's Opinion in Viking, above n 9, paras 38-40.

${ }^{59}$ Kumm, above n 48, 362-3.

${ }^{60}$ A Röthel, 'Grundfreiheiten und Private Normgebung' [2001] EuR 908, 915-6.
} 
main effect of granting horizontal direct effect to the fundamental freedoms is to turn European and national courts into the primary decision-making entities for balancing individual free movement with other relevant interests, whereas indirect horizontal effect coupled with the imposition of state duties on member states allocates such primary decision-making power to national legislatures and administrations. But in all cases the CJEU would still have a general jurisdiction to review decisions by national courts or legislators falling within the scope of the fundamental freedoms. ${ }^{61}$ This review would occur regardless of the relevant rights being directly or indirectly effective between private parties: it is the very conceptual structure of judicially enforceable constitutional rights that requires a court to determine whether some other public entities-legislatures, lower courts, maybe even public administration bodies-have acted in accordance with those rights or not. ${ }^{62}$ In short, whenever a situation falls within the scope of a judicially enforceable constitutional right, the ultimate substantive balancing exercise is incumbent on a judicial body; and this substantive balancing exercise is conceptually independent from, and will always take place regardless of, the type of horizontal effect adopted.

\section{Practical implications}

\subsection{The scope of the fundamental freedoms}

In light of the above, a first question to be addressed is that of the scope of the fundamental freedoms, which requires us to identify those private actions that should be regulated by them. ${ }^{63}$ A first building block in this is to recognise that when private actions are contrary to both national law and EU free movement rights, the relevance of the latter will be residual. These situations will be regulated by national law, even if such law may be subject to review under the fundamental freedoms. This limits our inquest to an attempt to identify those private actions that are both contrary to EU law and not expressly permitted or prohibited by national law as construed under the principle of interprétation conforme. ${ }^{64}$

\footnotetext{
${ }^{61}$ Kumm \& Comella, above $\mathrm{n}$ 46, 250.

${ }^{62} \mathrm{Kumm}$, above n 48, 365-6.

${ }^{63}$ E Engle, 'Third Party Effect of Fundamental Rights (Drittwirkung)' (2009) 5 Hanse L R 165, 173.

${ }^{64}$ Case 14/83 von Colson ECR 1891, Case C-106/89 Marleasing [1990] ECR I-04135, Case C-91/92 Faccini Dori [1994] ECR I-03325.
} 
A second building block is recognising that the fundamental freedoms are provisions which were drafted with the goal of creating an internal market. Since member states tend to be able to intervene in the functioning of the common market by restricting the activities of market participants in ways that private entities do not, public powers are the main addressees of the free movement provisions. The situation with private parties is different because in many circumstances private actors simply do not wield enough influence to successfully prevent others from enjoying their rights to free movement. Hence, it is arguable that what matters is that the restrictive effects on the market produced by private actions be similar to those produced by a state norm or a public act. ${ }^{65}$ This would be coherent with the normative underpinnings of the fundamental freedoms in creating an internal market: free movement provisions must only act where private action may endanger market unity, and accordingly private action may be caught by the Treaty rules on free movement only when it is not unlike state action, i.e. when it amounts to some sort of private legislation which restricts the free movement of economic factors. ${ }^{66}$

It could be argued, in light of this, that only measures or actions which are 'collective' in nature or regulate in a collective manner (by virtue of state delegation, or by having the character of private legislation or self-regulation allowed by the state) would have such an effect because they imply a 'power over individuals. ${ }^{67}$ This view, however, does not seem to be entirely correct. Not all state acts falling under the fundamental freedoms are general in nature; co-respectively, even though most private actions having a restrictive effect will probably be of a collective nature, there seems to be no good normative reason to limit the type of private actions which may fall within the scope of the fundamental freedoms to collective private actions. If what matters is the effect of an action, what is relevant is whether a private action's effect is similar to that of state action, not to state action's form. Thus not only collective, but also non-collective actions may fall within the scope of the fundamental freedoms. Although private non-collective actions with a sufficiently restrictive effect are unlikely to occur, there is no good a priori reason to exclude them from the scope of the fundamental freedoms. This effects-based rationale seems to have been adopted by the Court, which does not limit the actions that restrict free movement to acts imputable to quasi-public organisations, or to

\footnotetext{
${ }^{65}$ Orlandini, above n 23, 10; similarly for goods, Krenn, above n 30, 211.

${ }^{66}$ Cruz, above n 3, 105.

${ }^{67}$ Ibid, 121-5.
} 
associations exercising a regulatory task and having quasi-legislative powers', but has instead considered that actions by trade unions and by individuals, such as demonstrations or protests, can fall within the freedoms' scope. ${ }^{68}$

The Court even seemed to move beyond a merely effects-based rationale in Angonese and Raccannelli, by extending the general application of the prohibition of discrimination on grounds of nationality to situations exclusively between private parties. ${ }^{69}$ This development could be read as applying only to workers, but it has been expressly stated by the CJEU that the prohibition of discrimination on grounds of nationality between private parties also applies to the free provision of services. ${ }^{70}$ A close reading of Angonese also points in this direction: Angonese relies on Defrenne, which extended the only prohibition of discrimination with direct effect in the Treaty apart from that on nationality, namely the prohibition of discrimination in pay between men and women, to situations exclusively between private parties. ${ }^{71}$ Hence, a consideration of systemic elements would argue for the types of legal distinctions directly prohibited by the Treaty-namely the prohibition of discrimination on grounds of nationality and infringements on the imposition of equal payment between men and women in Articles 18 and 157 TFEU-being horizontally directly effective between private parties, regardless of the nature of the private action at hand. ${ }^{72}$

The Angonese and Raccannelli case law may be criticised both from a substantive and from an institutional perspective. From a purely substantive perspective, Angonese raises problems concerning the types of justifications that can be used by private parties to justify discriminatory conduct, particularly for actions without effects akin to state action. To allay this concern, it may be argued that Articles 15 to 17 of the Charter of Fundamental Rights-establishing, respectively, a general right for individuals to engage in work and to pursue a freely chosen or accepted occupation, a right to conduct a business, and a right to own, use, dispose of and bequeath his or her lawfully acquired possessions-provide general justifications requiring the core of (economic) private autonomy to be protected. These Articles can thus be used by individuals to justify their prima facie infringe-

${ }^{68}$ Commission v France, above n 20; Schmidberger, above n 21; Viking, above n 9; Laval, above n 9; and Raccanelli, above $\mathrm{n} 33$.

${ }^{69}$ Angonese, above $\mathrm{n} 12$; Raccanelli, above $\mathrm{n} 33$.

${ }^{70}$ Walrave, above n 7, para 17; Cruz, above n 3, 235.

${ }^{71}$ Case 43/75 Defrenne [1976] ECR 455.

${ }^{72}$ W-H Roth, 'Drittwirkung der Grundfreiheiten?' in M Lutter \& J Schwarze (eds), Festschrift für Ulrich Everling, vol II (1995) 1240-1. It should be noted that it is questionable how this applies to the free movement of goods or capital: see Oliver, above n 17, 81; Körber, above n 8, 951. 
ment of the market freedoms-unlike what the case is for member states, which may only have recourse to the exceptions provided for in the Treaty in what concerns discriminatory measures. ${ }^{73}$ But even if such a solution was found to be able to address this criticism, another, arguably more important criticism is that the Angonese case law seems to be at odds with the normative telos of the economic free movement provisions. This telos is to remove obstacles to the functioning of the common market; and while discriminatory measures by states can be presumed to create such obstacles, discriminatory conduct by specific individuals will usually not suffice for a restrictive effect on free movement to be found. ${ }^{74}$

From an institutional perspective, the Angonese case law may require courts to pursue balancing exercises whenever individuals discriminate on grounds of nationality, an exercise which may well exceed their scope or ability. By determining that all discrimination by individuals on grounds of nationality is a prohibited restriction of the fundamental freedoms, it becomes incumbent on courts to review those situations and to see whether private action was proportional; but this institutional allocation of competences was made both without taking into account courts' institutional limitations in pursuing such an assessment in all the individual situations that may come before them, and without considering the advantages of the available institutional alternatives-such as the adoption of national or EU measures subject to review by the CJEU, or taking into account the role that market competition may play. As has been argued by A-G Maduro:

The case of an individual shopkeeper who refuses to purchase goods from other Member States would not be liable to obstruct the functioning of the common market. The reason is that suppliers from other Member States would still have the opportunity to market their goods through alternative channels. Moreover, the shopkeeper would in all likelihood suffer from competition from retailers who had fewer qualms about buying foreign goods and who, as a result, might be able to offer lower prices and a larger choice to consumers. That prospect alone would probably be adequate to deter behaviour of this kind. Thus, the market will 'take care of it'. In those circumstances, there is no ground for Union law to intervene. The implication is that the rules on freedom of movement apply directly to any private action that is capable of

\footnotetext{
${ }^{73}$ Röthel, above n 60, 916; Schepel, above n 32, 197-8; Krenn, above n 30, 213-4.

${ }^{74}$ See, similarly, below n 75 .
} 
effectively restricting others from exercising their right to freedom of movement. ${ }^{75}$

As a rule, private parties are unlikely to have enough influence to prevent others from enjoying their rights to freedom of movement, and therefore, decisions applying horizontal direct effect should be exceptional. It is true that for states any discrimination on grounds of nationality is prohibited under the fundamental freedoms; but this relates to concerns about their specific powers in the normative, socio-economic, and cultural spheres, qua states. Any state measure which discriminates on grounds of nationality becomes immediately suspect of creating obstacles to trade and is subject to review or deemed to be prima facie unlawful. There is no reason for this to be the case for private action; accordingly, it should be specifically demonstrated that a private action discriminating on grounds of nationality restricts someone's right to free movement, thereby ensuring that the same concept of restriction is used for both states and private persons. ${ }^{76}$

Should one, however, be able to find a normative underpinning for the application of provisions prohibiting discrimination on grounds of nationality that is distinct and autonomous from the traditional normative underpinning of the fundamental freedoms-for example, in someone's personal status as an individual entitled to human rights or to European citizenship-the criticisms elaborated above concerning the institutional capacity of courts and the absence of consideration of other institutional alternatives would still apply. Should the Court still decide to tackle this matter, it could, to deal with these concerns and obviate the need for extensive and detailed balancing exercises in every case, look at how the EU legislature has dealt with issues of discrimination on grounds of sex, race or ethnic origin. Directives on equal treatment were adopted in these areas that can provide useful analogues for the prohibition of discrimination on grounds of nationality. ${ }^{77}$ These Directives state, in short, that, concerning access to and supply of goods and services which are available to the public, private actions which expressly discriminate on grounds of sex, race or ethnic origin should be prohibited unless specifically justified by legitimate

\footnotetext{
${ }^{75}$ Opinion in Viking, above n 9, paras 42-3.

${ }^{76}$ Similarly, for goods, see Krenn, above n 30, 211.

${ }^{77}$ Council Directive 2004/113/EC [2004] OJ L 373 implementing the principle of equal treatment between men and women in the access to and supply of goods and services; and Council Directive 2000/43/EC [2000] OJ L 180 implementing the principle of equal treatment between persons irrespective of racial or ethnic origin.
} 
requirements in the public interest. Similarly, a rule concerning the balancing of private autonomy and discrimination on grounds of nationality in the economic sphere could be elaborated along the following lines: discrimination on grounds of nationality in the supply of goods, services, business premises and housing by economic agents would be deemed unlawful except where it would constitute normal market behaviour. Otherwise, most private actions discriminating on grounds of nationality would be deemed acceptable, in particular when such actions constitute typical market behaviour. This rule would be in line with, and in addition to, the general orientations of the fundamental freedoms in pursuit of the aims of the internal market, without placing excessive burdens on private operators. $^{78}$ In effect, addressing the prohibition of express discrimination on grounds of nationality to suppliers, distributors and retailers open to the public at large would allow for the normal exercise of private autonomy while ensuring that courts are able to save their resources to deal with those borderline situations where the line between lawful and unlawful exercise of private autonomy has to be determined judicially.

\subsection{But what type of horizontal effect is to be preferred?}

Alongside the scope of the fundamental freedoms, there is another issue that requires our attention. It has been established that no substantive difference arises from choosing between different types of horizontal effect. From an institutional perspective, however, different types of horizontal effect correspond to different allocations of competences concerning the entities having primary decisionmaking responsibilities in balancing free movement with other legitimate public and private interests. Furthermore, the infringement of fundamental freedoms may give rise to civil liability, and thus to the payment of damages to the injured party. ${ }^{79}$ This means that, beyond looking into the scope of the fundamental freedoms, one also needs to discuss to what extent individuals or member states should be made responsible for private behaviour that infringes upon free movement rights. For both these purposes, one does indeed need to choose between different forms of horizontal effect.

Some authors argue that a mix of indirect horizontal effect and of protection duties by the states should be adopted in the EU context. The first reason for this

\footnotetext{
${ }^{78}$ Similarly, see Wyatt, above n 24, 16-31.

${ }^{79}$ This is not an academic question: see Raccanelli, above $\mathrm{n} 33$. See also a description of such a civil liability procedure in Sweden in M Rönnmar, 'Laval returns to Sweden: The Final Judgment of the Swedish Labour Court and Swedish Legislative Reforms' (2010) 39 ILJ 280.
} 
is that indirect horizontal liability by states-including both a duty to interpret national law in accordance with the fundamental freedoms by national courts and state liability in cases where omissions on a state's part leads to fundamental freedoms being infringed upon-covers all possible situations. Hence, this approach has the advantage of providing a single uniform solution by making the attribution of liability independent of the degree of regulatory intervention of particular states in private relationships. Another advantage to this approach is that, even though private parties might have recourse to the justifications provided in the Treaty, these are directed at states and not at individuals; it is hard to see how individuals might have recourse to them in practice. Yet another good reason for adopting this approach is that it leaves to the relevant member state the means to regulate private relationships in accordance with the principle of subsidiarity. Lastly, adopting a general indirect horizontal approach has the advantage of allowing for direct action against the member state for infractions caused by actions of private parties, arguably the reason why this approach was adopted concerning goods. ${ }^{80}$

It would in general be simpler, and more in accordance with the structure of the Treaty, to subject the horizontal effect of fundamental freedoms to a duty by national courts to interpret national law in accordance with the fundamental freedoms, coupled with some form of liability for breach of positive duties by states. ${ }^{81}$ Concerning damages, this approach would lead to an acceptable allocation of liability between states and private persons. Whenever a private party was found to have infringed upon both the fundamental freedoms and a national rule, that party would be liable for damages under national law; on the other hand, whenever the relevant structure to protect a fundamental freedom had not been put in place, by either member state omission or by the adoption of a law infringing upon the fundamental freedoms, the member state would then be liable for its failures in this regard. In other words, only member states could be held liable for infringements of the fundamental freedoms qua fundamental freedoms. ${ }^{82}$ From an institutional standpoint, it would be to courts' advantage to, as far as possible, allow a member state's legislative and administrative branches

${ }^{80}$ D Stoppel, 'Grundfreiheitliche Schutzpflichten der Mitgliedstaaten im Europäischen Gemeinschaftsrecht' (2003) 247-50 and 260-1; A McDonnell, A Review of Forty Years of Community Law: Legal Developments in the European Communities and European Union (2005) 149; Kingreen, above n 36, 578-83; Schillig, above n 39, 293.

${ }^{81}$ Against this, arguing for horizontal direct effect, see Schaefer, above n 8; arguing for both horizontal direct and indirect effect as complementary tools, see Krzeminska-Vamkava, above $\mathrm{n}$ 4,40 .

${ }^{82}$ Nevertheless, this normative position is not the position currently adopted by the CJEU in 
discretion on how to address private actions that might restrict free movement, without foregoing their powers to make sure that the exercise of discretion by the state duly protects the fundamental freedoms. ${ }^{83}$ The generalised submission of private action to judicial review under the fundamental freedoms would result in excessive legal uncertainty due to a completely open and unstructured process of balancing rights, risking the destruction of well-established private law concepts. ${ }^{84}$ What is more, if one takes into account the intrinsic limitations to the courts' institutional ability and resources, it becomes obvious that courts cannot be expected to review every single private action that might restrict economic free movement. The focus should be placed not on the specific conduct of private agents but on the interpretation of rules allowing or constraining such conduct, and exceptionally on the need for such rules. In exceptional circumstances where state regulation is absent, it cannot be excluded that the best option may occasionally be to apply the constitutional right directly to the situation at hand, while still deeming the state to be liable for its failure to act; this, however, would need to be assessed on a case-by-case basis reflecting the exceptional nature of those situations.

\section{Conclusion}

The present article argues that, instead of focusing exclusively on whether private parties are direct addressees of the EU fundamental freedoms, the question of the freedom's horizontal effect can be more fruitfully understood as relating to their scope. Traditional debates focusing on the intended addressees of the Treaties' provisions can only provide limited guidance in understanding and have a very limited descriptive ability to explain the current state of the law. If, instead, one thinks of the EU's fundamental freedoms as constitutional rights, and realises that the issue of horizontal effect is a common problem of constitutional law, this permits a comparison of EU law with other constitutional systems. Such a comparison illustrates how the fundamental freedoms, like other constitutional rights, can apply to purely private relationships without any relevant substantive distinction arising from the type of horizontal effect they are deemed to have.

cases other than those on the free movement of goods; see P Szczekalla, 'Grundfreiheitliche Schutzpflichten - eine Function der Grundfreiheiten des Gemeinschaftsrechts' (1998) 113 DVBl 219.

${ }^{83}$ K Muylle, 'Angry Farmers and Passive Policemen: Private Conduct and the Free Movement of Goods' (1998) 23 ELRev 467, 473-4.

${ }^{84}$ Schillig, above n 39, 306 
A preliminary question as to what type of horizontal effect is preferable concerns the scope of the fundamental freedoms. It is argued that, in the light of the Treaty and of the instrumental nature of the fundamental freedoms to the creation of an internal market, in determining this scope one should focus on the restrictive effect of certain measures or actions regardless of their public or private origin-in other words, the concept of restriction should be the same regardless of the public or private nature of the agent pursuing a certain course of action, even if it is accepted that public action can usually be presumed to have restrictive effects in a way that private action cannot.

On the other hand, substantive equivalence does not mean there are no relevant implications to the choice of applicable type of horizontal effect. Different types of horizontal effect lead to different outcomes concerning which organisation has primary responsibility for balancing the different interests at play, and who is liable for damages caused by restrictions to free movement. In the light of the specific comparative advantages and disadvantages of courts and legislatures, the structure of the Treaty, and the instrumental nature of the free movement rights to the creation of the internal market, indirect horizontal effect-imposing a primary duty on states to balance free movement with private autonomy and other relevant interests, subject to review by the CJEU-coupled with the imposition on states of a duty to protect free movement rights would be the best option, and thus should be adopted across the fundamental freedoms. 